\title{
Angiotensin in ECMO patients with refractory shock
}

\author{
Marlies Ostermann ${ }^{1^{*}} \mathbb{D}$, David W. Boldt ${ }^{2}$, Michael D. Harper ${ }^{3}$, George W. Lim² and Kyle Gunnerson ${ }^{4}$
}

Refractory vasodilation and catecholamine resistance are common in septic shock. Changes in receptor signaling, excessive production of nitric oxide, and absolute or relative deficiencies of vasoactive hormones, including cortisol, vasopressin, and angiotensin II, play a role. Angiotensin II (Ang II) was previously available as a vasopressor but removed from the market in the 1990s. Interest was re-ignited following the Angiotensin II for the Treatment of Vasodilatory Shock (ATHOS-3) study, a randomized controlled trial in patients with refractory shock which confirmed that Ang II was effective at maintaining mean arterial pressure and reducing norepinephrine requirements without an increase in side effects [1]. Patients receiving renal replacement therapy also had improved survival and faster recovery of renal function [2]. Recent literature noted the potential role of Ang II in other types of shock [3].

The major physiological effects of Ang II relate to maintenance of hemodynamic stability and fluid and electrolyte regulation (Table 1). Angiotensinogen, the precursor of angiotensin, is produced primarily by the liver and released into the systemic circulation where it is converted to angiotensin I (Ang I). Ang I is cleaved into Ang II, predominantly by angiotensin converting enzyme (ACE), an endothelium bound protein that is primarily expressed in the pulmonary and renal capillary beds. In patients with acute respiratory distress syndrome, ACE insufficiency has been reported [4]. In veno-arterial ECMO, a proportion of blood bypasses the lungs, which further limits the conversion of Ang I to Ang II. Other conditions associated with reduced Ang II levels include Gramnegative sepsis where endotoxinemia can deactivate ACE. Importantly, low levels of Ang II and ACE are associated with increased mortality [5].

We report the successful management of seven patients (four male; mean age 36 years) with severe cardiorespiratory failure and refractory shock treated with extracorporeal membrane oxygenation (ECMO) who received Ang II in the context of the ATHOS-3 trial [1] or a compassionate use program (Table 2). Following initiation of Ang II, a profound effect on blood pressure was seen and the doses of vasopressors were reduced quickly. Time to cessation of vasopressors and catecholamines ranged from $16 \mathrm{~h}$ to 8 days. Six patients were discharged home alive.

In conclusion, in patients with severe cardio-respiratory failure requiring ECMO, treatment with Ang II in addition to standard supportive care enabled rapid decatecholaminization. Underlying ACE deficiency may be a contributing factor. Further studies are necessary to confirm the findings.

\footnotetext{
* Correspondence: Marlies.Ostermann@gstt.nhs.uk

'Department of Critical Care, King's College London, Guy's \& St Thomas'

Foundation Hospital, London SE1 7EH, UK

Full list of author information is available at the end of the article
} 
Table 1 Main physiological effects of angiotensin II

\begin{tabular}{|c|c|}
\hline Organ system & Physiological effects \\
\hline Vascular & $\begin{array}{l}\text { - Vasoconstriction of venous and arterial vessels } \\
\text { - Increased vascular permeability }\end{array}$ \\
\hline Renal & $\begin{array}{l}\text { - Stimulation of } \mathrm{Na} \text { reabsorption and } \mathrm{H}^{+} \text {excretion in the proximal tubule via } \mathrm{Na}^{+} / \mathrm{H}^{+} \text {exchanger } \\
\text { - Stimulation of the release of aldosterone } \\
\text { - Variable effects on glomerular filtration and renal blood flow depending on the physiological and } \\
\text { pharmacological setting: } \\
>\text { constriction of the afferent and efferent glomerular arterioles with greater effect on the efferent vessel } \\
>\text { constriction of the glomerular mesangium } \\
>\text { enhanced sensitivity to tubulo-glomerular feedback } \\
>\text { increased local release of prostaglandins which antagonize renal vasoconstriction }\end{array}$ \\
\hline Endocrine & $\begin{array}{l}\text { - Stimulation of the secretion of vasopressin from the posterior pituitary gland } \\
\text { - Secretion of ACTH } \\
\text { - Enhanced release of noradrenaline from postganglionic sympathetic fibers }\end{array}$ \\
\hline Nervous & - Enhancement of noradrenaline secretion \\
\hline Cardiac & - Mediation of cardiac remodeling through activated tissue RAS in cardiac myocytes \\
\hline Coagulation & - Prothrombotic potential \\
\hline Immune & $\begin{array}{l}\text { - Promotion of cell growth and inflammation } \\
\text { - Increased expression of endothelium-derived adhesion molecules } \\
\text { - Synthesis of pro-inflammatory cytokines and chemokines } \\
\text { - Generation of reactive oxygen species }\end{array}$ \\
\hline
\end{tabular}

Abbreviations: ACTH adrenocorticotropin hormone, Ang Il angiotensin II, GFR glomerular filtration rate, RAS renin-angiotensin system

Table 2 Patient characteristics

\begin{tabular}{|c|c|c|c|c|c|c|c|}
\hline & Patient 1 & Patient 2 & Patient 3 & Patient 4 & Patient 5 & Patient 6 & Patient 7 \\
\hline Age (years) & 23 & 26 & 41 & 48 & 38 & 50 & 37 \\
\hline Gender & M & M & $\mathrm{F}$ & $\mathrm{F}$ & M & $\mathrm{F}$ & M \\
\hline Primary acute illness & Influenza A infection & Sepsis & $\begin{array}{l}\text { Influenza B and MRSA } \\
\text { pneumonia }\end{array}$ & $\begin{array}{l}\text { Sepsis post } \\
\text { acute Ml }\end{array}$ & Aspiration pneumonia & Pulmonary embolism & $\begin{array}{l}\text { Type A } \\
\text { aortic dissection }\end{array}$ \\
\hline $\begin{array}{l}\text { Secondary acute } \\
\text { illness }\end{array}$ & $\begin{array}{l}\text { Cardiac arrest due to } \\
\text { pericardial effusion }\end{array}$ & Cardiac arrest & $\begin{array}{l}\text { Sepsis and cardiogenic } \\
\text { shock }\end{array}$ & & $\begin{array}{l}\text { Drug overdose (calcium } \\
\text { channel blocker and } \\
\text { beta blocker) }\end{array}$ & Multi-organ failure & $\begin{array}{l}\text { Poly-microbial } \\
\text { sepsis }\end{array}$ \\
\hline Confounding factors & None & $\begin{array}{l}\text { Idiopathic dysautonomy } \\
\text { and mast cell activation } \\
\text { syndrome }\end{array}$ & Obesity & HIV positive & Obesity & $\begin{array}{l}\text { Recent craniotomy } \\
\text { for meningioma }\end{array}$ & $\begin{array}{l}\text { Large RV and } \\
\text { LV infarct }\end{array}$ \\
\hline Type of ECMO & VA ECMO & VA ECMO & VA ECMO & W ECMO & W ECMO & VA ECMO & VA ECMO \\
\hline $\begin{array}{l}\text { Vasopressor support } \\
\text { *pre-Ang II } \\
\text { administration }\end{array}$ & $\begin{array}{l}\text { Norepinephrine } 0.4 \\
\text { Vasopressin } 4 \\
\text { Epinephrine } 0.07\end{array}$ & $\begin{array}{l}\text { Norepinephrine } 1 \\
\text { Vasopressin } 6 \\
\text { Epinephrine } 0.3\end{array}$ & $\begin{array}{l}\text { Epinephrine } 0.18 \\
\text { Vasopressin } 2\end{array}$ & $\begin{array}{l}\text { Norepinephrine } \\
0.59\end{array}$ & $\begin{array}{l}\text { Norepinephrine } 1.36 \\
\text { Vasopressin } 2.4\end{array}$ & $\begin{array}{l}\text { Norepinephrine } 0.2 \\
\text { Vasopressin } 5 \\
\text { Milrinone } 0.25 \\
\text { Epinephrine } 0.05\end{array}$ & $\begin{array}{l}\text { Norepinephrine } 0.1 \\
\text { Vasopressin } 4 \\
\text { Epinephrine } 0.02\end{array}$ \\
\hline $\begin{array}{l}\text { MAP at initiation of } \\
\text { Ang II [mmHg] }\end{array}$ & Missing & 57 & 76 & 70 & 63 & 59 & 59 \\
\hline $\begin{array}{l}\text { Dose of Ang \| } \\
\text { [ng/kg/min] }\end{array}$ & Missing & Missing & 20 & 20 & 40 & 20 & 20 \\
\hline Duration of Ang II & & & 7 days & $46 \mathrm{~h}$ & $50 \mathrm{~h}$ & $27.5 \mathrm{~h}$ & $80 \mathrm{~h}$ \\
\hline $\begin{array}{l}\text { Time to cessation of } \\
\text { all vasopressors after } \\
\text { initiation of Ang \| }\end{array}$ & Missing & $48 \mathrm{~h}$ & Missing & $16 \mathrm{~h}$ & 6 days & 8 days & NA \\
\hline $\begin{array}{l}\text { Adverse events } \\
\text { during Ang II } \\
\text { infusion }\end{array}$ & None & None & $\begin{array}{l}\text { Reversible digital } \\
\text { ischemia }\end{array}$ & None & None & None & Bowel ischemia \\
\hline Patient outcome & Survival & Survival & Survival & Survival & Survival & Survival & Deceased \\
\hline $\begin{array}{l}\text { Duration on ECMO } \\
\text { [days] }\end{array}$ & 17 & 5 & 119 & 4 & 9 & 9 & 14 \\
\hline $\begin{array}{l}\text { Length of stay in } \\
\text { ICU [days] }\end{array}$ & 176 & 30 & 128 & 21 & 22 & 13 & 14 \\
\hline
\end{tabular}

Abbreviations: Ang II angiotensin II, ECMO extracorporeal membrane oxygenation, ICU intensive care unit, LV left ventricle, MAP mean arterial pressure, MRSA methicillin-resistant staphylococcus aureus, $R V$ right ventricle, $V A$ veno-arterial, $W$ veno-venous 


\section{Abbreviations}

ACE: Angiotensin converting enzyme; Ang I: Angiotensin I; Ang II: Angiotensin II; ATHOS: Angiotensin II for the Treatment of Vasodilatory Shock; ECMO: Extracorporeal membrane oxygenation

\section{Acknowledgements}

The authors would like to thank the patients for allowing the publication of their anonymized data and contributing to the dissemination of information. We are also grateful to the research nurses and coordinators who helped with the successful conduct of the ATHOS -3 study.

\section{Funding}

Not applicable.

\section{Availability of data and materials}

The datasets used and analyzed during the current study are available from the corresponding author on reasonable request.

\section{Authors' contributions}

$\mathrm{MO}$ wrote the first draft of the paper and $\mathrm{DWB}, \mathrm{MDH}$, and $\mathrm{KG}$ revised the draft. GWL is a clinical fellow who helped with data collection. All authors reviewed the drafts, provided input, and approved the final version.

\section{Ethics approval and consent to participate}

The case series includes patients who participated in the ATHOS-3 study or received angiotensin II in the context of a compassionate treatment program. The ATHOS-3 study was fully approved by an independent research ethics committee.

\section{Consent for publication}

As part of the ATHOS-3 study, patients gave consent for their data and results to be published in an anonymized format.

\section{Competing interests}

The authors declare that they have no competing interests.

\section{Publisher's Note}

Springer Nature remains neutral with regard to jurisdictional claims in published maps and institutional affiliations.

\section{Author details}

'Department of Critical Care, King's College London, Guy's \& St Thomas' Foundation Hospital, London SE1 7EH, UK. ${ }^{2}$ Department of Anesthesiology and Critical Care Medicine, UCLA Healthcare System, West Los Angeles, USA. ${ }^{3}$ Integris Baptist Medical Center, Nazih Zuhdi Transplant Institute, Oklahoma City, USA. ${ }^{4}$ Departments of Emergency Medicine, Anesthesiology and Internal Medicine, Michigan Center for Integrative Research in Critical Care, University of Michigan, Ann Arbor, MI, USA.

Received: 29 September 2018 Accepted: 10 October 2018

Published online: 01 November 2018

\section{References}

1. Khanna A, English SW, Wang XS, et al. Angiotensin II for the treatment of vasodilatory shock. N Engl J Med. 2017;377(5):419-30.

2. Tumlin JA, Murugan R, Deane AM, et al. Outcome in patients with vasodilatory shock and renal replacement therapy treated with intravenous angiotensin II. Crit Care Med. 2018;46(6):949-57.

3. Busse LW, McCurdy MT, Ali O, Hall A, Chen H, Ostermann M. The effect of angiotensin II on blood pressure in patients with circulatory shock: a structured review of the literature. Crit Care. 2017;21(1):324.

4. Orfanos SE, Armaganidis A, Glynos C, et al. Pulmonary capillary endothelium-bound angiotensin-converting enzyme activity in acute lung injury. Circulation. 2000;102(16):2011-8.

5. Zhang $W$, Chen $X$, Huang $L$, et al. Severe sepsis: Low expression of the renin-angiotensin system is associated with poor prognosis. Exp Ther Med. $2014 ; 7(5): 1342-8$. 